\title{
CARTOMANCIE (1952-1999): LIVRO DE ARTISTA, POESIA EM JOGO
}

\section{Francisco Oiticica Filho}

Resumo: Este estudo vai enfocar alguns aspectos do estatuto artístico do livro moderno e contemporâneo vinculado à crise da noção de autoria até há pouco profundamente marcada, ainda, pelo mito romântico da originalidade. Serão apresentados exemplos de saída para essa crise e, em seguida, iremos tratar do caso particular de recriação artística de Cartomancie (Paris: La Presse à Bras, 1952), livro escrito, ilustrado, e impresso pelo pintor e poeta modernista brasileiro Vicente do Rego Monteiro (1899-1970).

A reedição desse pequerio livro, acontecida em Recife, em 1999, concretiza o projeto original da publicação de Cartomancie no formato de um baralho. O seu percurso editorial reúne, a nosso ver, as condições de análise dos muitos problemas estéticos que, enunciados durante o alvorecer das primeiras vanguardas artísticas do século $\mathrm{XX}$, repercutem em novas formas de colaboração imagem-texto e se atualizam na releitura intersemiótica realizada na pós-modernidade.

Palavras-chave: Autoria; poesia; arte moderna; Vincent do Rego Monteiro.

La parole modulée/ est fumée/ envolée/ tandis que le mot écrit/ vit encore sur son support/ Merci papier/ Merci plume/ Merci encre/ Je vous suis fidèle/ à en crier.

Vincent Monteiro (Poèmes, 1951).

"Ceci sera cela" ("Isto será aquilo"), dizia Victor Hugo, em Notre Dame de Paris (1831). O escritor francês, e também aquarelista precursor do livro de artista, saudava a arte da imprensa ao contemplar a catedral, opondo o livro ao edifício. O poder que a pedra

- Doutor em Literatura, Cultura e Sociedade (PPGLL-UFAL).

Publicou Enfim, primitivos: estudo cultural do modernismo brasileiro (Maceió, Edufal, 1999) e Vincent Monteiro, poeta cordial: marcas textuais de sociabilidade literária - Paris 1946-1960 (Maceió, Edufal, 2004). 
representou, em termos de segurança e estabilidade para a civilização antiga, o papel representaria para a sociedade moderna, substituindo a estabilidade inerte do edifício pela agilidade de circulação do livro. O homem se libertava do peso da autoridade imposta pelo monopólio do saber, porquanto o livro devia conter em si a sua própria chave de interpretação. Assim, se a catedral é "pensamento em pedra", o livro, "pássaro em liberdade". A catedral havia significado, até então, o ápice da cultura ocidental. Fixando seus alicerces na cidade e apontando suas agulhas para o céu, a arquitetura do templo realizava a concepção metafísica da representação, servindo de modelo para a paginação do texto sagrado. Com a reprodutibilidade técnica que a imprensa preconiza, são demolidos os fundamentos de uma ordem transcendente, e a cultura torna-se muito mais obra de apropriação, espetáculo e consumo, do que de devoção, recolhimento e contemplação.

"O livro vai matar o edifício", prosseguia Victor Hugo. De fato, a metáfora militar de que a vanguarda futurista, no século $X X$, se valeu declarou guerra à ditadura do verbo imposta ao livro tradicional. Daí o clamor de Marinetti para que se queimassem as bibliotecas. Tratava-se já de impor um outro tipo de livro ("de artista", como veremos) contra aquele que organizava a informação em retângulos c colunas: o livro da tradição judaico-cristã cujo protótipo é a Bíblia. Em seu ascetismo particular, esse modelo para todo livro ocidental primeiro livro impresso por Gutemberg - reproduzia em escala reduzida a disposição hierática do templo sagrado.

A Bíblia era fonte dominante desde a Idade Média, e o principal objeto de leitura. Näo se tratava de algo ao qual se acedia pela interpretação, mas sim por uma leitura condicionada pela exegese que dirigia a aplicação do texto segundo regras determinadas pelo sistema. O acesso ao livro estava amparado no fundamento da prática religiosa determinando a nossa entrada $\mathrm{em}$ seu recinto segundo as mesmas regras de decoro, pudor e severidade do ritual religioso tradicional.

A etimologia do termo religião diz bem de uma certa imbricação entre o escritural e o arquitetônico do sagrado: religião significa "re-ligar", o que remete à formação de uma comunidade e à participação do fiel no ritual praticado em uma assembléia, enquanto locus bem definido, e, por outra, significa, também, "re-colher", o que 
remete ao ato de coligir a doutrina que faz um texto. Estariam colocados, assim, os aspectos de continente (templo-livro) e conteúdo (livro-texto) da pragmática do sagrado. Pois é justamente dentro do templo que o livro é conservado, operação que sacraliza ambos os espaços.

O livro continua ainda profundamente inscrito, por outro lado, na perspectiva romântica de realização de uma estética da expressão pessoal, horizonte de realização do estatuto autoral de quem adentra a esfera cultural. A visão genial do artista é um mito romântico da imaginação livremente criativa. O que se percebe, com a assunção de uma certa lógica contestatória das vanguardas, no século $\mathrm{XX}$, transposta e ampliada para a esfera de produção do livro de artista, é que a "arquitetura" do livro que se apoiava em um texto-revelação sagrado foi abalada, expondo as marcas de um contexto particular e historicamente datado.

A obra, não sendo uma criação que surge do nada, parte de um quadro de referência aprioristicamente dado, a partir do qual pode ser entendida e apreciada. Ela é necessariamente atravessada por textos e tradições provenientes de outros sistemas de representação, de tempos, e de gêneros diferentemente situados. O próprio conceito de "obra", ou o de "autoria", é sacrificado, na medida em que se reconhece que não há texto fechado em si, fundamento da origem identitária dos discursos. O sujeito, como autor do texto, cede a primazia aos ideologemas, função que liga uma estrutura literária concreta a um conjunto social considerado como conjunto textual.

Conseqüência disto é que caem por terra a concepção de originalidade absoluta e a condenação de imitação, com implicações na elaboração da retórica livresca baseada no princípio da autoridade.

A midiatização do livro deriva da invenção da imprensa. Com ela, nascera o "homem tipográfico", reduzindo a totalidade da experiência à escala de um só sentido: a visão. No entanto, os hábitos ditados pelo uso do livro, enraizados nesse homem, condicionaram o percurso do olhar à organização linear e seqüencial de leitura dos enunciados verbais. Com os circuitos elétricos, na modernidade, reintroduz-se a percepção humana do mundo na multidimensionalidade primitiva de uma barbárie pensada em sua potencialidade de transformação positiva. 
A humanidade ocidental passou de um modo de registro de dados classificatórios para o de uma interação global. Entretanto, quando se tratava de transcrever uma poesia essencialmente feita para a orelha, o papel da tipografia permaneceu secundário. Nos primeiros textos impressos, a preocupação era imitar a letra manuscrita, de modo a se aproximar de uma autenticidade da palavra proferida pela voz de uma presença originária. Daí os textos sagrados resistirem mais à incorporação das inovações advindas das técnicas de reprodução mecânica.

A tipografia marca esta primeira separação. Ela compõe o conjunto de procedimentos de diagramação do texto eminentemente escrito. Com a perda de relevância da rima e da métrica, na poesia, o branco tipográfico se tornou a principal marca de separação de estrofes e de pausa de leitura. Mas a tipografia atua decisivamente também no interior da linha: certos poetas concretistas aumentam o tamanho do corpo e o espaçamento entre palavras para obter o efeito que não permite a pontuação ordinária. A poesia contemporânea tem, por sua vez, a tendência a se utilizar o máximo possível do branco da página, a ponto de não deixar subsistir nada além de duas ou três palavras.

\section{Categorias estéticas do livro-arte}

A reivindicação do estatuto de obra de arte para o livro surge de uma revisão do conceito de veículo de comunicação e forma significativa que o leva ao confronto com a natureza do fenômeno literário. Um livro não é apenas suporte do verbo, mas tudo o que o faz "volume", isto é, a textura do papel, o seu cheiro, as retículas de impressão. As marcas do tempo sobre o livro nos indicam que ele é um objeto pleno de sentidos. Ele é o conjunto de operações que formata o texto e o configura no espaço da página, condicionando sua recepção estética e impondo a sua lógica de leitura nas disposições das linhas, na diagramação, na apresentação, elementos que distribuem ao longo do volume as marcas paratextuais dos saberes dos quais o livro precisou se valer para existir. Mas o livro está aquém e além desse parentesco, ele também depende da apropriação que the é dada pelo usuário, que se investe da sua própria fisicalidade expressiva para percorrê-lo e explorá-lo. 
Embora possamos vasculhar o contato imagem-texto desde os livros manuscritos medievais, o que concebemos aqui como livro de artista encontra seus predecessores na França, durante a segunda metade do século XIX. Será o processo editorial que vai conferir ao livro a consistência de obra de arte, dai o interesse em que o próprio artista participe da editoração.

A disputa pelo controle dos processos de produção afeta a linguagem do livro de artista. $\mathrm{O}$ aspecto figurativo das imagens apresenta um elemento formal que modifica nosso contato com o livro, fazendo-nos compartilhar com a leitura uma outra modalidade de acesso não-intelectual, mas contemplativa. A ilustração introduz um olhar estereoscópico na unidade do livro, e um ritmo inusual, de onde a competição entre as manchas de texto e imagem.

A imagem adentrou o espaço do livro como um elemento perturbador. Vista isoladamente, ela não pode ser considerada nem verdadeira nem falsa, pois não trata de uma proposição no senso lógico, como enunciado que estabelece uma relação causal entre dois termos. $O$ argumento visual permanece um "enunciado simples e implicito, a expressão de uma opinião" (JOLLY, 1994, p. 176). A imagem amplia, desse modo, o sentimento de posse através daquele corte, negando a neutralidade inicialmente prevista para o livro como veículo de um conteúdo de verdade absoluta.

Ao fïnal do século XIX, o real é invadido pelo fíccional, são as fotografias, as estátuas nas ruas, os cartazes. Escritores "iconófobos" e escritores "iconófilos" vão fazer dessas imagens o objeto de seu interesse, vendo nelas o signo de emergência da imaginação. Uma nova estética aflora na conjunção texto-imagem situada no livro, percepção do mundo pela composição em justaposição e lateralidade, cores planas, hibridismos formais, jogo com a negatividade da vida, leitura rápida e em zig-zag, enquadramentos descentralizados da paisagem, rapidez de descrição e multiplicação de enunciados descritivos, mudanças abruptas de escalas, formas breves e simplificadas, fragmentação do enredo em cenas sugerindo quadros.

Fausto (1828), de Goethe, que contava com litografias de Delacroix, e as litografias que Manet realiza para o poema "O corvo" 
de Poe, traduzido por Mallarmé (1875) e editado por Richard Lesclide, são exemplo de parceria no livro ilustrado.

Esse filão editorial foi desenvolvido na França por editores tais como Phillipe Burty, que organiza a publicação de Sonnets et eaux-fortes (1869), reunião de 42 gravuras e 42 poemas encomendados, pelos poetas, a Verlaine, Gauthier, Hérédia, e, pelos pintores, a Hugo, Monet, e Millet. Em 1900, Ambroise Vollard promove a realização de Parallèlement, com poemas de Paul Verlaine e litografias de Pierre Bonnard, considerado também um precursor do livro de artista. Tratou-se de satisfazer uma demanda bibliófila que fez. os artistas modernistas internacionais se engajarem na pesquisa por um diálogo entre o visual e o verbal especialmente produzido para ser transmitido pelo livro.

De olho no crescente mercado do livro ilustrado, Kahnweiler, Vollard, Skira, e outros editores, no século XX, alimentaram o desejo de bibliófilos amantes de pequenas e valiosas tiragens, produzidas para o deleite privativo de colecionadores. Uma das características desse mercado de livros de luxo era a pequena tiragem, garantida pela destruição posterior das pranchas originais, impedindo, assim, novas tiragens. O livro ilustrado partia de uma encomenda e propunha uma colaboração do artista com o autor do texto, enquanto o livro de artista, em comparação, é inteiramente controlado por um só autor, encarregado de realizar ou acompanhar todas as suas etapas de produção.

Os exemplos desses álbuns ilustrados, no entanto, não afetaram a indústria do livro, nem suas realizações questionaram o livro como obra. Apesar de representar uma saudável renovação ornamental, feita menos para ser lida do que vista, o livro ilustrado do século XIX não extravasou o retângulo branco do papel, funcionando como sucedâneo da tela de cavalete. Essas experiências, em razão de

Quando de uma dessas encomendas, ocorre um incidente entre Mallarmé e o editor: o poeta recusa o pedido de participação em obra coletiva devido à sua concepção de que a escritura bastaria a si mesma, diante da possibilidade de ver scu texto ilustrado. A obra em questão é aquela editada por Burty, anteriormente citada (La genèse du livre de peintre. Le Men e Scott, 1990, p. 43 e nota 23). 
não interrogarem a forma conceitual ou material do livro, permaneceram presas ao compromisso da colaboração sem reivindicar para o livro a legitimidade do conteúdo informativo de que é portadora a realidade sensivel do material

\section{Livro: obra de artista}

Contestado pelos poetas, a partir do final do século XIX, o princípio da contigüidade do discurso verbal foi contraposto a uma escritura paradigmática simultaneísta. Àquela configuração perceptiva correspondia um pensamento domesticado e conformista, alhcio à heterogeneidade do real à volta. A linguagem verbal prosaica que se propagou no livro tinha como forma estética a linearidade discursiva, apreendida de uma sucessão de frases organizadas sintagmaticamente que impõe uma mecânica de leitura seqüencial hierarquizada. Aberto para a complexidade de estimulos do meio social, o movimento modernista vai exigir outro espaço artístico com a objetivação de livros fora do convencional.

A categoria estética pela qual se manifesta este fenômeno é a do livro de artista. Para delimitarmos o campo, vamos nos valer de uma definição de Riva Castleman, especialista inglesa: "Livros de artista são isto - a obra de um artista cujo imaginário mais do que estar submetido ao texto supera-o para traduzi-lo dentro de uma linguagem que tem mais significados do que as palavras sozinhas podem transmitir" (apud SILVEIRA, 2001, p. 36).

$\Lambda$ proliferação dos gêneros levou à distinção entre o livro de luxo, ilustrado; o livro de artista, baseado $\mathrm{cm}$ um diálogo imagemtexto; e o livro-objeto, peça escultórica feita como um comentário ao livro. Esse movimento segue o impulso anticlássico da arte moderna, a partir das experiências de ruptura de linguagem das vanguardas estéticas do inicio do século XX.

Algumas de suas referências importantes vieram do cubismo: "O português" (1911), tela em que Georges Braque utilizou letras pintadas com normógrafo criando quadros para serem, também, "lidos", e "Natureza-morta com cadeira de palha" (1912), de Pablo Picasso, que inovou ao trazer colado à superficie do quadro um pedaço de encosto de uma cadeira real. Estava criado, assim, o princípio da colagem artística, que muito iria influenciar a estética do livro moderno e contemporâneo. 
Vários são os exemplos bem sucedidos de novos agenciamentos de texto e imagem em objetos que têm no livro o seu modelo. Em 1913, com La prose du Transsibérien, Blaise Cendras e Sonia Delaunay elaboram aquele que seria considerado o primeiro livro simultâneo. Realizado em sanfona, sobressai, mais do que o texto de Cendras, a longa pintura de Delaunay que recobre os dois metros da superfície estendida do livro. Eminentemente visual, mais do que verbal, "sua fisicalidade, bem como aparência dessa fisicalidade prescindem do texto escrito" (SILVEIRA, 2001, p. 154).

Guillaume Apollinaire, em 1918, publica Caligramas, poemas da paz e da guerra, inovando a diagramação da página impressa ao juntar no texto poético a escrita e o desenho. Seus poemas visuais, a que deu o nome de caligramas, permitem-nos escutar o eco dessa hiperestesia, com a exploração das analogias entre conceito e imagem, fazendo as palavras e a sua figuração conviver em um corpo só. Apollinaire, em apresentação a esse livro, definiu assim seus caligramas: "une idéalisation de la poésie vers-libriste et une précision typographique à l'époque où la typographie termine brillamment sa carrière, à l'aurore des moyens nouveaux de réproductions qui sont le cinéma et le phonographe".

Outra tendência do livro modernista foi de cunho racionalista, ao propor uma organização funcional de espaço que desemboca em uma concepção de livro como objeto de design. A obra gráfica da Bauhaus vai reconduzir a tipografia ao caminho da ordem construtivista, regida pelo propósito de clareza e de tornar persuasiva a mensagem veiculada. A publicação de Bauhaus 1919-1923 é uma espécie de manifesto que faz do autor, Moholy-Nagy, um dos precursores do livro industrial. Escolhendo caracteres menos ornamentais que funcionais, a Bauhaus elaborou um projeto gráfico que prescreve o mesmo padrão de execução afeito tanto à construção arquitetônica quanto a de um objeto do mobiliário doméstico.

Pode-se ressaltar também a tendência ao livreassociacionismo como uma modalidade de escritura que requisita uma nova concepção de paginação. Nela se baseava o jogo surrealista chamado "cadavre exquis": várias pessoas reunidas passam umas às outras sucessivamente um papel sobre o qual cada uma delas escreve uma palavra ou traça uma linha. Acaba-se por obter uma variedade de frases inverossímeis, ou um desenho que desafia a realidade. O 
exemplo se tornou clássico, e o jogo veio a ser conhecido pela primeira frase assim obtida: "cadáver refinado". O que resulta daí são imagens justapostas a palavras que se agrupam por contraste, com o sentido produzido pela transferência de significados entre vocábulos desconectados gramaticalmente uns dos outros.

Ponto comum dessas realizações é o questionamento do conceito de texto e leitura. Essa discussão ocupou boa parte das vanguardas do século XX. A escrita automática e a assemblage, as colagens e o ready-made incorporam a incerteza e a heterogeneidade do mundo, do que são exemplos as obras citadas, vontade de introduzir um pouco da complexidade do real na obra de arte.

Com a realização de obras únicas, ou de tiragens limitadas, mais ligadas ao artesanato, e por meio da autopublicação c da autodistribuição, o livro de artista assume uma postura não-negativa mas dialética diante do literário. Hoje, travando um embate contra toda subordinação a interesses comerciais, o livro de artista promove um contato afetivo com o leitor baseado em uma concepção que tem na leitura a via através da qual se retomaria o caráter autônomo da experiência estética. Assim, a conotação utópica do livro ressurge como espaço de reflexão do sujeito promovida através dessa fruição individual do objeto, refreando a contagem usurária do tempo ditada pelos interesses impostos por uma ordem utilitária.

\section{A poética modernista do livro de artista em Mallarmé}

A proposição revolucionária de Stéphane Mallarmé fez a idéia do livro-obra acontecer. Até Mallarmé, apesar da extraordinária proliferação de imagens nas artes do livro, as páginas de texto eram geralmente concebidas pelas livrarias sem outro projeto que de uma lisibilidade sem maiores atrativos, com grandes margens e entrelinhas, visando apenas dilatar artificialmente o volume.

Preocupado com a incorporação da heterogeneidade e complexidade do real, ao que identificava o controle do acaso, Mallarmé iria propor em Un coup de dés jamais n'abolira le hasard (1897) uma idéia de criação artística, que, na forma de um "poema-partitura", anunciava uma nova física do livro. De modo a verificar essa possibilidade, Mallarmé construiu um pocma que se voltava sobre si mesmo, poema crítico baseado na confrontação de páginas com indicações temáticas reversíveis à estrutura do livro. 
O Livro, projeto literário e editorial de Mallarmé, do qual o poema-partitura é um fragmento, rejeitaria a idéia usual de livro adotando os princípios da permutação e do movimento como aspectos estruturais. As folhas poderiam ser mudadas de lugar e lidas de acordo com a manipulação de um novo leitor-operador. O propósito de um "probabilismo integrado à fatura mesma da obra de arte como elemento desejado da composição" (CAMPOS, idem), patente nas obras de arte modernas, constava da proposta de fazer com que o volume, apesar da impressão fixa, se tornasse através desse jogo algo móvel.

O campo semântico e o sistema operacional do jogo iriam estar presentes nas realizações a partir dai voltadas para a combinatória de configurações possíveis, permitindo uma liberdade dirigida onde atuariam processos de seleção e descarte das muitas combinações propostas dos elementos de base, aumentando as possibilidades de leitura de um multilivro. O propositor, e não mais o autor em sentido tradicional, vai incorporar em sua sintaxe as possibilidades de alterações, vincando a necessidade de uma experimentação sensorial com a manipulação real do objeto.

A contribuição maior de Mallarmé para a estética do livro seria, então, pensar a literatura junto com o projeto gráfico, implícito na percepção do livro como obra de arte. Le coup de dés inauguraria outro espaço, propriamente "literário", modificando-se a relação espaço-tempo no livro, pois que o branco da página é figurado enquanto elemento significante, voltado tanto para a representação do silêncio entre as palavras e interior à linguagem, quanto à representação de um espaço de pausa e reflexão do leitor.

Le coup de dés formula dois problemas que nos trazem ao bojo de nosso assunto: do ponto de vista gráfico ele acrescenta ao estabelecimento do texto um problema de ordem de paginação; e, do ponto de vista lingüístico, ele nos coloca, a partir do inacabamento de seu poema, do qual não dispõe a língua francesa de nenhuma edição de referência incontestável, um problema de tradução diante do aspecto necessariamente intersígnico da obra. Pois a edição de 1914, na revista Cosmopolis, na qual veio ao mundo uma versão do esboço desse projeto, se afastava bastante daquilo que Mallarmé queria: produzir um efeito antes de tudo visual. 


\section{Cartomancie: a sorte está lançada}

Si on ne peut plus tricher avec ses amis, ce n'est plus la peine de jouer aux cartes.

Marcel Pagnol

Assim como a obra de Mallarmé, Cartomancie, de Vicente do Rego Monteiro, veio a público incompleta. Justamente pelo mesmo motivo, o forte apelo visual do poema, e também pela afinidade temática, trabalhada em outro registro e radicalidade. Le coupe de dés e Cartomancie incorporam o principio do jogo à fatura literária. Em ambas as experiências existiria, como condição de leitura interpretativa, uma margem de indecisão e indeterminação na escolha dos meios de tradução, uma certa irredutibilidade à condição de "coisa", no sentido de algo que escapa ao caráter instrumental de apetrecho para reclamar ser deixado "repousar em si mesmo" (IIEIDEGGER, 1990, p. 26). Qualquer tentativa de tradução editorial de ambos os poemas deveria, portanto, se deparar com esse efeito de perspectiva que os caracteriza, o qual exige uma leitura atenta não só aos aspectos sonoros mas também aos significantes tipográficos.

Os primeiros trabalhos de Monteiro no campo das artes do livro são fundamentais para apontar os motivos e os temas que desenvolverá logo em seguida na pintura, e as questões de conteúdo que irão ocupar um lugar de destaque em sua poética posterior. A saber: com Legendes, croyances et talismans des indiens de l'Amazonie (Paris: Tolmer, 1923); Découvertes sur la danse, do mesmo editor Louis Duchartre (1924); e Quelques visages de Paris (Paris, Juan Dura, 1925), primeiro livro de sua inteira autoria, Monteiro vai trabalhar em três obras gráficas exemplares de seu percurso artístico e existencial, cada qual girando em torno de uma questão essencial: em 1923, a mitologia nativa e a questão da identidade nacional; em 1924, a mundanidade e a assimilação dos hábitos cosmopolitas; e, em 1925, o encontro cultural sob a ótica do "falso primitivo" como ficcionalização da experiência pessoal de integração de Monteiro à modernidade.

Apesar de reconhecermos a importância dessas obras, o que vamos, a partir daqui, tratar é do caso da recriação de Cartomancie, livro de 1952 que melhor exemplifica a categoria de livro de artista em questão. E, ademais, concebido inicialmente como livro de poemas 
temáticos, ficou "fechado em copas" e não se completou até que em 1999 aparecesse um grupo de estudiosos brasileiros formado por Paulo Bruscky, Mário Hélio e Ronildo Leite que desse a Cartomancie o formato definitivo. ${ }^{2}$ A promessa contida no título do livro, "leitura do futuro através de uma espécie de jogo de baralho", de que nos fala Leyla Perrone-Moysés, foi realizada em 1999, o que nos permite acesso, agora, verdadeiramente, a Cartomancie na forma de um baralho. Com ele, vamos tentar jogar, maneira de aceder mais cerradamente ao texto.

Quem aprecia a arte moderna brasileira conhece o pintor Vicente do Rego Monteiro. De onde, creio, a surpresa, contida neste artigo, de um contato mais estreito, quando não inicial, com a figura de um Monteiro poeta e editor. Deparamo-nos, aqui, com uma referência feita não a uma de suas preciosas pinturas dos anos 1920, com as quais constrói a reputação na "Escola de Paris", mas a Cartomancie, coletânea de poemas de 1952 impresso em sua La Presse à Bras, editora particular que se valia de uma prensa manual montada em seu ateliê parisiense (XIVème, rue Didot, $\mathrm{n}^{\circ}$ 117).

Queremos, também, cotejar o formato novo que Carlomancie recebeu, quando da publicação de sua segunda edição, com a unidade locucional "livrobjetojogo". Essa noção encontra-se exposta $\mathrm{em}$ um texto avulso de Paulo Bruscky (apud SILVEIRA, 2001, p. 290), um dos responsáveis pela reedição do livro de Monteiro, relacionado a multimeios. Com essa expressão neológica, Bruscky quereria mostrar a diferença de seu trabalho como criador de livro-objetos, que se encontra na fronteira entre as artes, em relação ao que considera uma expressão "bem comportada, convencional", baseada na relação "contemplativa" com a obra, ao que contrapõe a "utilização de multimeios e o contato continuado com pessoas" fruto de uma estrutura proposicional mais "aberta" e "solta" do jogo (BRUSCKY apud SILVEIRA, idem).

2 Contando com outros colaboradores, foi publicado, em 2004, definitivo levantamento crítico em catálogo bilíngüe, gráfico e sonoro, da obra poética completa de Monteiro (Vicente do Rego Monteiro: poeta, tipógrafo, pintor. Recife: Cepe, 2004). 
A definição de livro-objeto, pré-requisito para o entendimento do significado do neologismo brusckyano, é matéria em franca discussão, atualmente. Nele, se destaca a materialidade do suporte enquanto forma significante que o identifica ao aspecto escultórico que o livro assume. Livro-objeto se define como um "objeto de arte que alude à forma do livro" (PHILLPOT apud SILVEIRA, 2001), enquanto "livrobjetojogo" se refere a um caso específico de livroobjeto voltado mais do que nunca à participação interativa do público usuário mobilizado pelo aspecto lúdico e prazeroso de experimentação da leitura em contexto diferenciado, pois que agrega "outros elementos de forma a produzir uma quase infinita série de resultados" (BRUSCKY apud SILVEIRA, 2001, p. 291).

Estaria, pois, voltado para a elaboração de um livro-jogo o conteúdo do projeto que Bruscky levou adiante em suas próprias obras e a prática de leitura que exercitou em contato com os poemas de Cartomancie, baseada no desencadernamento dos poemas.

Admirador do Monteiro tipógrafo e fonógrafo, do poeta e do pintor que transitava pelas expressões artísticas as mais diversas, Bruscky se apropria de Cartomancie para explicitar a relação de comentário e suplementação de texto e imagem que o livro continha em estado de potência. Assim, com o empenho de seus colegas pesquisadores de Recife, transforma o livro de Monteiro, uma coletânea de poemas acompanhados de vinhetas, em um livrobjetojogo, aproximando-o de suas experiências radicais de leitura não-verbal do livro que realiza enquanto artista multimeio, o que afeta o processo de recepção estética da obra impressa.

\section{Monteiro: artista (tipo)gráfico ${ }^{3}$}

A partir de 1946, Monteiro volta a morar em Paris. No exíguo apartamento da rua Didot, $\mathrm{n}^{\circ} 117$, em que Monteiro e sua mulher Marcelle passaram a residir, havia tão somente um cômodo, sendo que

3 Os neologismos, ou mots-valises, são para Monteiro a manifestação de jeux d'esprit na linha da condensação de significados que Freud apontava como um dos processos fundamentais da imaginação simbólica e que Monteiro desenvolve, marcantemente em Poemas de bolso (Recife, 1946): CRISOCRIPTOCOSMO. 
metade do espaço disponível dessa peça única era ocupada pela sua prensa manual, e a outra metade ocupada pelas telas de Monteiro, ainda existentes, seus livros, o material para impressão necessário, o mobiliário e os demais pertences do casal (Depoimento Apercelle).

Monteiro havia trazido consigo, de Recife, onde se refugiou durante a Segunda Grande Guerra, alguns componentes da prensa manual com que funda sua editora La Presse à Bras (1946- 1957), e onde passa a imprimir, nesse apartamento, suas poesias, cada vez mais numerosas, e a de toda uma geração de poetas de língua francesa, sob a égide da amizade. São plaquettes singelas e portáteis, livros da coleção que denominou Poésie de poche, voltados, como diz o nome da editora, para serem manuseados, aderindo à vida e circulando entre as pessoas no cotidiano.

Prensa mecânica de tipos móveis, e nome de sua editora, $L a$ Presse à Bras exerceu em Paris uma atividade importante de viabilização de uma poesia amadora, no melhor sentido de uma criação que remunera de maneira antes de tudo afetiva os seus produtores.

Cartomancie permaneceu um livro incompleto desde sua primeira edição, em razão de ter sido publicado em formato diferente do pretendido pelo autor. Acumulando as funções de escritor, ilustrador, diagramador, editor e gráfico de seus livros, e de seus inúmeros amigos poetas de Paris, Monteiro pretendia conferir a Cartomancie o formato de um jogo de cartas e não pôde. Premido pelas múltiplas atividades e pelos constrangimentos de ordem técnica que padronizavam os métodos de impressão em sua gráfica artesanal, Monteiro deixou para as gerações futuras a tarefa de conclusão de seu projeto editorial.

Os 32 poemas anteriormente editados em formato brochura que Monteiro imprimiu foram recriados pelo grupo de Recife, em homenagem ao centenário do poeta. Os poemas de Cartomancie se apresentam impressos na face de cada uma das cartas de um baralho, mensagens enigmáticas convidando ao jogo e à decifração, à margem do literário na metáfora naipesca.

O clichê, tão importante para a fixação dessa nova sensibilidade, e motivo recorrente na filtragem dos estímulos colhidos do cotidiano urbano, aparecerá duplamente empregado: enquanto 
poeta, Vincent desempenha, como editor, a função de um "homem tipográfico". A sua concepção de arte, portanto, segue o exemplo da atividade fabril e artesanal que trancava nas oficinas os impressores de incunábulos.

O clichê é uma imagem presente na imersão de Monteiro no universo do impresso, pois, ao se voltar para a poesia, e se tornar um escritor de expressão francesa, Monteiro forja um "tipo", "móvel" e disponível para o trabalho "gráfico". Pode-se imaginar com isso um processo de adoção de uma nova pátria, apoiada pela La Presse à Bras e pela linguagem poética, o que fez Perrone-Moysés afirmar que seus versos, mesmo quando em português, dão a impressão de que foram escritos na outra língua.
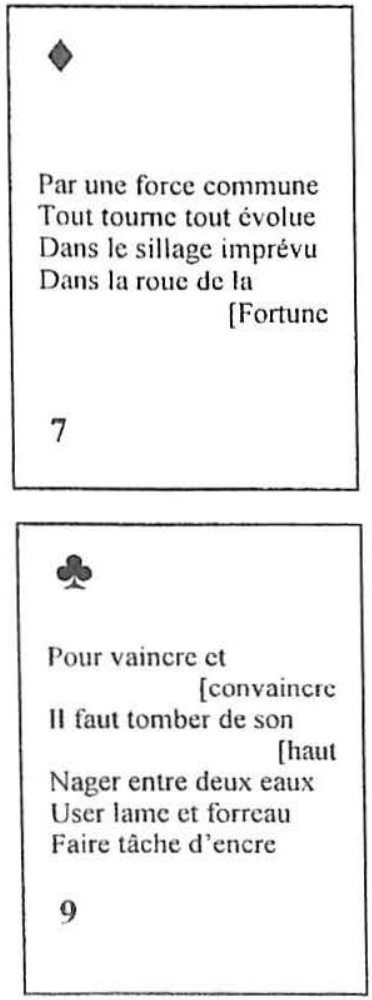

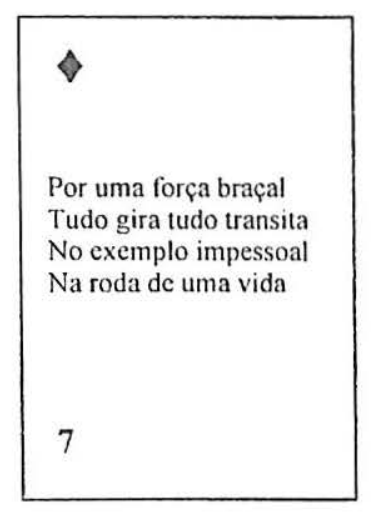

\section{4}

Para vencer e convencer

E preciso cair do altar

Entre correntes nadar A ferro e fogo moldar Serviço duro fazer

9 
A impressão de livros de poesia passa a ser sua atividade principal, com a escassez da pintura. Monteiro abandona, então, 0 nome luso-brasileiro e adota o prenome francês - Vincent. No trabalho de tipógrafo, a partir de 1946 em Paris, é que podemos vê-lo em simbiose com sua prensa manual e entender a antropomorfização de seu equipamento expressa na escolha de um trocadilho corrente, " $\mathrm{La}$ Presse à Bras", "A Prensa a Braço", para denominar a sua editora. A imagem dessa simbiose entre o poeta e os tipos móveis passaria a ser tematizada em seus versos. Dois exemplos de Cartomancie que, vertidos por nós para o português, tematizam essa simbiose (tipo)gráfica estão acima representados.

\section{Cartomancie, livro-baralho medieval}

O livro-baralho é uma metáfora que, vinda da Alta Idade Média, se encontra documentada em textos peninsulares do século XVI, chegando a ser encontrada até o século XIX (ETIÈNVRE, 1990, p. 100). Em 1593, na Espanha, encontra-se, já, uma definição que aproxima o livro do baralho: "Baraja, o Baraja de naipes. Llaman en españa a un librete de ojas, o cartas sin enquadernar que vale por pieças de un juego a que llaman de naipes" (Diego de Guadix. In: Recompilacion de algunos nombres arabigos, apud ETIÈNVRE, 1990 , p. 104). O baralho é um livro reduzido, pois não tem nunca muito mais do que quarenta páginas, mas um livro, ainda assim, pois tem em comum um suporte tipográfico independente e idôneo para assegurar-lhe pronta difusão.

Revestidos de uma aparência modesta, os trabalhos de Monteiro são fruto de pesquisa acurada. De um lado, encontra-se na tradição da poesia cancioneira espanhola, desde o século XV, um exemplo, recolhido por Etiènvre, de "juego con el qual se puede jugar como con dados o naypes" (ETIÈNVRE, 1990, p. 16), conforme o livro-baralho de Monteiro: trata-se de Juego de naipes de Fernando de la Torre, poema medieval "extraño", ao mesmo tempo texto e baralho. Antes de ser texto, os versos estão distribuídos por cada uma das 48 cartas em "una magnifica baraja preparada, segun indicaciones muy pontuales del poeta, por un miniaturista de la Corte" (ETIÉNVRE, 1990, p. 17). Dedicado à condessa de Castañeda, esses versos foram escritos para falar de quatro tipos de amores, cada um deles identificado a uma cor e um naipe. 
De outro, vamos ver, no século XIX, as cartas de jogo como objeto de culto da intimidade burguesa. Uma certa coleção de "cartas de jogo adivinhatórias, editada por Grimaud em Paris, na segunda metade do século XIX" (dossiê Art et Décoration, $n^{\circ} 389$, p. 114) e que faz parte da coleção do Museu Francês de Cartas de Jogo, apresenta evidentes semelhanças com Cartomancie, especialmente quanto aos motivos e objetos do jogo em questão. De uma parte, Monteiro pesquisa tradições de escrita, e, de outra, formas diferentes de editoração do livro. Assim, ele trabalha a linguagem poética com o rébus, o epigrama, e o calembour, e ao mesmo tempo o livro de emblemas, o baralho, a plaquette.

\section{"A poética do naipe", achegas para a definição de livrobjetojogo}

No conceito de jogo é que Cartomancie adquire o sentido mais contemporâneo de texto, dilatando o significante para fora das regras de legibilidade. Daí, poderíamos chamar sua recriação de 1999 de um livro-jogo, ou mais especificamente, através de outro neologismo, como previa Bruscky, de um livrobjetojogo.

A poética da emulação, valor clássico, volta a ser praticada na contemporaneidade, depois de rechaçada pelos românticos que valorizaram a ruptura e a diferença. Aquela idéia de uma originalidade absoluta é, todavia, irrealizável, havendo, quando menos, um padrão discursivo comum aos escritores de um mesmo período, refutando-se a idéia de um texto cuja geração dependesse unicamente do autor. $\mathrm{O}$ que foi aperfeiçoado na emulação de Cartomancie foi o processo de leitura, que encampou o aleatório através da linguagem combinatória de poemas dispostos em páginas "desencadernadas" do livro-baralho, em nova diagramação do formato no espaço em que aquela edição original se transformou.

A condição de divertissement que é inerente ao jogo nada teria de depreciativo do ponto de vista do labor poético exigido em Cartomancie. Muito pelo contrario, inscrita na tradição da célebre fórmula "prodesse et diletare", de Horário, escrita em torno de I a.C., a obra deveria ser não só fonte de prazer para os sentidos, isto é, "deleitar", como também ser "instrutiva". O princípio de que o autor deve "ensinar e recrear" implica que o leitor deva, a seu tempo, "aprender e se deleitar" com a obra. Este desígnio, manifesto na expressão horaciana, significava que o autor que ambicionasse o 
reconhecimento dos seus contemporâneos e a passagem para a posteridade deveria saber "misturar o útil ao agradável, pois deleita e ao mesmo tempo ensina o leitor" (HORÁCIO, s/d, p. 107).

Ora, o vazio criado pela ociosidade das classes dominantes só poderia ser combatido pelo trabalho e pelo recreio. Pascal escreveu acerca desta necessidade moral do divertimento: "Que se faça a prova: deixemos um rei a sós, sem nenhuma satisfação para os sentidos, sem nenhum conforto no espírito, sem companhia, a pensar que ele possa se distrair sozinho; e se verá que um rei sem divertimentos é um miserável." (apud HATHERLY, 1995, p. 150). balada:

Rei desamparado este a quem Monteiro dedica a seguinte

Ce
pauvre
sire
se révolte
virevolte
vire
vote
$\mathbf{R}$

Trata-se de considerar a poesia o espaço privilegiado para sc realizar o paradoxo do jogo, qual seja, unir o desejo de liberdade com a paixão pela regra. Falar de poesia lúdica seria, portanto, incorrer em um pleonasmo. $\Lambda$ poesia é jogo porque à norma do verso se justapõe 0 gosto pelas imagens, correndo paralelamente à métrica e à semântica. No jogo poético, todo o poder desprende da linguagem, com a qual o poeta conta para informar a realidade. Na possibilidade combinatória, no aspecto enigmático da arte, na motivação da linguagem poética vamos ver demonstrada a íntima ligação que faz o lúdico e o lúcido confluírem no poema.

O jogo de cartas é o único a admitir simultaneamente o agôn, a "competição", e o alea, a "sorte", o que confere à metáfora do jogo uma superioridade absoluta quando se trata de representar toda atividade que leve em consideração a leitura do destino, a adivinhação, a antecipação do futuro. Monteiro conjuga texto e imagem em um só jogo semântico, visual e fônico. No poema acima, a 
figura do "senhor" (de si) jogador é confrontada com as peripécias pelas quais a carta de jogo passa, matéria e agente sendo jogados um sobre o outro em um espelhamento contínuo e solidário. O formato da mancha gráfica reproduz o naipe de ouros antecipando as "reviravoltas" que o jogo (da vida, na mesa) dá, ao tempo em que a ambigüidade de sentido no jogo de palavras aposta na equivocidade do discurso que tem na sorte seu cavalo de batalha.

Ao se utilizar da metáfora naipesca, o homem força a história a se comportar de acordo com finalidades teleológicas, ou seja, tenta abolir o acaso, de acordo com resultados previamentes colocados. $\mathrm{O}$ jogo construiria uma irrealidade como antecipação dos fatos, interpondo a sua interpretação àquela construída pela história. A metáfora naipesca vem colocar à prova a irredutibilidade de ficção, jogo, e história. A fortuna da história-discurso, que efetivamente se assemelha ao jogo, faz com que a história-objeto se abra para o contingente e o imprevisível que subsiste no interior da chamada "realidade dos fatos".

\section{Poesia e adivinhação}

A disposição desordenada dos poemas é um condicionante do texto mágico, pois que as cartas vêm de uma tradição dos cerimoniais de adivinhação em que os presságios estavam preservados da curiosidade daqueles não iniciados por uma escritura cifrada de caráter sigiloso. Interpretar sua mensagem era penetrar em uma ordem cósmica enigmática na qual o sagrado escrevia as suas leis. O locus deste ritual é a mesa, de jogo, de adivinhação, onde gira a "roda da Fortuna":

Par une force commune

Tout tourne tout évolue

Dans le sillage imprévu

Dans le roue de la Fortune

Assim como os jogos de cartas passaram a ser aproveitados da mitologia para o ensino, e para a diversão, com a multiplicação de outros jogos de sociedade sob o mesmo suporte, a sentença enigmática com que se manifesta o cartomante, no livro de Monteiro, não esconde mais o seu objeto, saindo do contexto do ritual sagrado para se 
manifestar em não importa que situação do cotidiano. O poema, como outra via de enunciação, se mostrou terreno fértil para exploração das diversas formas de enigma: charada, rébus, anagrama, são algumas das formas verbais de sentença enigmática que se vê na sua poesia. ${ }^{4}$

O gênero lírico se ajusta bem ao enigma, porquanto este deriva mais de uma situação vivida do que de um objeto de conhecimento provado. O enigma é um enunciado cifrado que tem com o gênero lírico uma afinidade estética, recorrendo ambos, muitas vezes, aos vocativos, à interrogação e à exclamação, colocando em xeque a existência humana, na medida em que a decifração de um enigma sempre constituiu questão de vida ou morte.

A sentença enigmática está na origem da literatura, pois ela serve de ponto de partida para o mito: assim é que falavam os oráculos, e é neles que o poeta se inspira.

A imagem da "Consultante" (adivinho) vem exercer seu poder de sedução, que se condensa no vaticínio, incitando, sob todo o risco, a continuar o jogo:

\author{
$\mathrm{O}$ \\ Consultante \\ Si tu tiens au beau \\ consul tente \\ ta chance coupe \\ encore une \\ fois \\ D
}

Resulta daí a desmontagem do cogito, movida pela polissemia da metáfora naipesca, onde, por exemplo, a palavra "coupe" - "corte" e "copas"-, no poema, reflete a natureza do embaralhado dos naipes, das cartas, e revela a operação de montagem e desmontagem do sujeito.

4 Foram os padres jesuitas que, no século XVII, introduziram as cartas de "jogos de brasões", em suas escolas européias, como maneira de facilitar o aprendizado da heráldica (Cf. PALASI, 2000). 
No mesmo movimento de desvirar as cartas, páginas de um livro desencadernado, o jogador é colocado em jogo. O sujeito que se quereria exterior ao jogo para melhor manipulá-lo, a salvo de qualquer risco inerente à partida, está irresistivelmente colocado "em jogo". No ato mesmo de jogar, é ele quem estaria desde então sendo jogado.

A recriação de Cartomancie como jogo de cartas fornece as condições para a formulação do enigma. Não existiria melhor meio de introduzir a sentença enigmática que pelo jogo, pois que este se coloca provocativamente quanto ao real, pondo, logo, em questão o estatuto de eficácia da objetividade de toda interpretação.

A proposição enigmática se apresenta segundo um certo modo de enunciação: o ponto de vista colocado sobre um assunto destaca apenas algumas das partes conhecidas do objeto, indicando uma existência mascarada, desconhecida; ele destaca a importância deste desconhecido ao qual atribui a sua razão de ser, conferindo uma importância maior à invisibilidade deste real dissimulado do que à sua parte visivel.

O enigmático constitui um desafio para o espírito, pois a existência escondida por trás da máscara não é somente atraente, ela estimula a busca, a exploração de seus contornos, mesmo que a procura reste indefinida e o objeto desconhecido. Que o nome desse objeto possa ser pronunciado ou não, e vimos, em Vincent, (o nome como persona, como figuração do sujeito) a importância disto, sua existência persiste mascarada na sentença enigmática, mesmo que sua identidade seja determinada.

A ambigüidade do enigma está de acordo com a virtualidade do sujeito lírico, que, desprovido de identidade estável, se investe de inúmeras aparências. O sujeito do poema não é outra coisa que uma de suas representações possiveis que a escritura inventa, uma figura mítica da poesia, uma encarnação da potência do verbo.

O conto "A cartomante" (1896), de Machado de Assis, é emblemático no sentido de situar a metáfora naipesca na condução da intriga, permitindo uma interpretação que levou Alcides Villaça a investigá-lo como procedimento que permite "entrever-lhe uma representação do mundo e de si mesmo" (VILLAÇA, 1998, p. 3-15). 
Através da figuração lírica, Monteiro desprende-se da interpretação da história tradicional dedicada à anamnese do passado alheio (influência da arte indígena das pinturas primitivistas que poderia ser rastreada conforme esperimentara nos anos 1920) para se lembrar daquilo que jamais houve lugar. Sujeito hyperminésique (MAULPOIX, 1996, p. 160), ele tudo viu e compreendeu, salvo ele mesmo. A obra revela e oculta a verdade daquilo que é: um poeta, para "contar sua impossivel biografia", se constitui de inúmeras vozes que se interceptam, palympseste de visages aimés (MAULPOIX, idem).

Qual um oráculo, Monteiro expressa uma voz ouvida à distância. Mas, nesse estado, o poeta sente-se que já não se pertence mais: a voz interpela o sujeito que a ouve portadora de uma mensagem vinda do longínquo. Mais que objeto do conhecimento, o enigma surge de uma situação vivida que implica uma mudança na relação do sujeito com a realidade. Confrontado com um enigma, o sujeito não coincide mais com o seu mundo habitual. Ele percebe as coisas como algo ao mesmo tempo estranho e familiar, como se ele já fosse um "outro". Seja através de um jogo de palavras, ou da ambigüidade de imagens, o enigma exprime um trabalho do inconsciente no limite da estabilidade do real. O poeta, relevando de seu conhecimento simbólico, faz aparecer o enigma que a arte em si mesma é.

Recriar Cartomancie na forma de um jogo de cartas é colocar à disposição do leitor um equipamento que servia para planejar a vida da comunidade. A adivinhação através da decifração dos enigmas contidos em cartas era tomado em alta conta pelas sociedades tradicionais. Constituia a escritura um conjunto de preceitos a serem seguidos de modo a favorecer uma boa conjunção astral. Com Cartomancie, a mesa de leitura vira mesa de jogo, e a apreensão individual do livro um jogo de sociedade.

\section{A leitura de Cartomancie}

No livro ilustrado, o espaço era vivenciado segundo uma temporização prévia, prevista no encadernamento, e a leitura se encontrava ritmada pelo ato de folhear as páginas, enquanto, agora, ele é atravessado pelo espaço ambiente. Mais do que nos álbuns de folhas soltas, onde também ocorreria esse atravessamento, aqui, a intromissão é mais profunda porque necessária. 
O livro nos transmite sua experiência incomum de tempo. Ingressamos com o livro em uma temporalidade ontológica que é a do estado permanente de queda, pois enquanto vivemos não podemos jamais alcançar um estado de equilíbrio estável, muito menos de repouso. A convivência com os livros nos adverte de nossa constante incompletude, análoga à característica do folhear que se realiza equacionando o movimento e o espaço. Esse tipo de disposição realiza o tempo e condiciona a recepção da informação, podendo se constituir ela mesma em um dado fundamental de análise de conteúdo do livro:

A peine né l'homme s'endort

Sa peine finie il s'endort

En somme sa vie est encore

L'apprentissage de la mort

7

O "ser-para-a-morte" é um aprendizado de vida que nos individualiza, pois que esta experiência não pode ser vivida por procuração: "A morte dos outros é o fim do mundo deles, não do seu; ela ocorre no interior de seu mundo, não do mundo dos que morreram, e será lembrada por você, não por eles" (REE, 2000, p. 48). Assim, de modo semelhante à projeção da morte na vida, que chama a atenção para a autenticidade de nossa existência, ao ler um livro criamos um mundo em que o ser está situado frente a frente consigo mesmo enquanto "ser-no-mundo". Salvamos o livro para a vida, tirando-o do repouso em que se encontrava, e cle nos devolve nossa temporalidade.

As cartas colocadas na mesa para leitura de uma escriturapresságio exigem uma incorporação do acaso em uma interpretação afirmativa das relações entre adivinhação e jogo. Porque é por uma aproximação metafórica da poesia à linguagem cifrada das escrituras esotéricas que o futuro se materializa no poema, à medida que as cartas são reviradas e sua interpretação é feita.

Vê-se a importância da metáfora naipesca para a realização daquela função mágica que a linguagem já teve, dada a capacidade de a metáfora mostrar as coisas sem precisar justificá-las. Ao leitor caberá interpretar o livro como o texto da vida, para reaprender a ler a vida como texto de um livro aberto ao agir. Trata-se de injetar um conteúdo de novidade no poema com o paradoxal reenvio do texto à 
forma ancestral do jogo de cartas, quando a escritura se prestava para uma leitura do futuro. Essa novidade vai estar inscrita no "desencadernamento," ato de antecipação da promessa de leitura do futuro que faz o livro.

O branco tipográfico, que, introduzido por Mallarmé, ganha uma importância cada vez mais afirmada na página escrita, atinge escala ambiental, pois, ao invés de encadernadas no livro, as páginas estão soltas e sugerem outras práticas de leitura diferentes, mais lúdicas e dessacralizadas. À medida que essas cartas são distribuídas entre os jogadores, ou colocadas à mesa para adivinhação, dependendo do uso que se faça delas, o branco, surgido do desaparecimento do verso e do silenciamento da rima no poema, é integrado ao espaço virtual de jogo.

Guardados em uma caixa de papelão, quando destacados da embalagem, os poemas de Cartomancie se dispersam. O livro só estaria completo com as cartas em repouso, porque assim é que todas as cartas seriam reunidas. Porém, essa inteireza do livro em repouso não nos permitiria saber nada do seu ser. Um livro fechado encontrase em repouso, e um livro em repouso está quase morto.

O livro fechado nada significaria, enquanto dependente de seu formato. No estado de abertura que opera o desencadernamento é que Cartomancie nos lança na incerteza e nos riscos inerentes à vida. Aporia da vida que o jogo alegoriza, não há sentido possível sem que se assuma o risco de tudo perder no jogo, quando, no estágio de livro inicial, imóvel e calado, sairá de repouso um texto para nos dizer algo de nosso próprio modo de ser.

A "morte do verso" sentenciada por Mallarmé, a qual o advento da espacialização do poema tematiza, no entanto, deve ser reencenada por cada novo poema, enquanto experiência de um sujeito lírico que não pode viver a morte por procuração. Essa experiência

6 O "livro-desencadernado" é um qualificativo que aparece ao final do século XVI em vários textos cabendo à definição das cartas de jogo: "Los naypes son otro libro, aunque desenquadernado, adonde los ociosos también estudian. Esta es su Biblia, donde sacan sus figuras y puntos, y no de oración" (Pero de Guzman, in "Bienes del honesto trabajo y daños de la ociosidad" (1614). In: ETIÉNVRE, 1990, p. 323). 
insubstituível terá de ser articulada a um novo lirismo a partir do diagnóstico de que, com o esvaziamento de sentido da experiência pessoal, marcada pelo horror das duas guerras, a subjetividade entra em crise. Uma transfiguração do real se libera com a redução de motivos e uma tomada de posição ética diante das coisas, das quais se retém sua singeleza e fragilidade.

Tal é o que se depreende do poema:

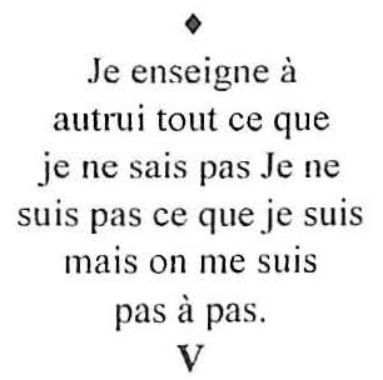

Existiria uma tomada de consciência de si na leitura que o naipe antecipa, confirma e amplia. Ponto de inflexão de uma interpretação literal para uma apreensão fusional da experiência de recordação poética, os naipes de cartas dão o mote da canção de Vincent. São o pré-texto que recupera a informação na passagem de um para outro poema; são o referente que situa os poemas na realidade do jogo.

No dizer de Leyla Perrone-Moysés, as aparentes "brincadeiras" das experiências formais na poesia de Monteiro "se revelam extremamentes sérias". Nesse poema, Monteiro atualiza a conhecida indagação existencial expressa na charada do "Qui suis-je?", ou "Quem sou eu?", que diz muito da condição de ser exilado do poeta que vai buscar conforto na identidade alheia e refúgio na tradição emprestada pela qual ele paga com a doação de si mesmo. Segundo aquela estudiosa, Monteiro "joga com a linguagem contra a solidão, a doença, a velhice, e seu humor é uma nobre conquista". Isto é o que Cartomancie coloca em jogo: a diferença do reenvio a si que se pode ler na poesia monteirina, no enfrentamento e na realização da condição de seu cosmopolitismo. 


\section{Monteiro pintor, Vincent poeta}

No texto de apresentação da nova edição, Aposta na poesia, Mário Hélio, de quem partiu a idéia da recriação de Cartomancie, relata a surpresa de João Cabral, poeta, e também tipógrafo, ao saber, por seu intermédio, da existência de 16 livros de poesia de Monteiro. Surpresa ainda maior deverão estar tendo os demais leitores agora, que ainda não tiveram acesso a uma obra que acaba de ser redescoberta. Acontece com sua a poesia o mesmo que se passou com a sua pintura: depois de sua participação na Semana de 22, ela só veio a ser revista em 1966, no Masp, a convite de Pietro Maria Bardi, seu diretor, que não sabia da existência de Monteiro como pintor da "Escola de Paris", revelação feita pelo poeta Géo-Charles, amigo de Monteiro, e seu agente francês.?

A figura do "esquecido", em tudo o que ela importa de distanciamento, recuo e ultrapassamento, no tempo e no espaço, parece constituir uma dominante na poética monteirina, levando-a a ir buscar em um tempo outro, em um espaço inventado, as fontes de inspiração para as telas e os poemas:

Je suis l'oubli

Et la tendresse

Le ciel de lit

Que le temps dresse

8

Da civilização marajoara que o Brasil não viu, à Idade Média que o Brasil não teve, se estende a pesquisa de motivos que Monteiro trabalha, para uma atualização da questão da superação dos limites territoriais do imaginário para além das fronteiras nacionais e do contexto histórico, invenção esta que não abdica, no entanto, da figuração de um sujeito lírico na qual se desdobra a imagem do

7 Géo-Charles, "poeta olimpico" francês, reuniu uma coleção de obras de arte e documentos da cultura artistica francesa do período do entreguerras que deu origem ao Museu Géo-Charles da cidade de Echirolles, França. Seus arquivos são importante fonte de consulta sobre a carreira de Monteiro no exterior. 
Vicente do Rego Monteiro pintor recifense do bairro da Boa Vista, na do Vincent poeta e tipógrafo parisiense da rue Didot, figuras que se reconhecem a "si-mesmo como um outro". 8

Em sua pintura, Monteiro situa o jogo de cartas no encadeamento metafórico de imagens a meio caminho da troca de papéis sociais e da personalidade artística que só o momento de poeta realizaria. A passagem do Monteiro pintor para o Vincent poeta é mediado pela atividade de tipógrafo. O livro assume, desse modo, importância capital em seu percurso artístico e existencial.

Durante os anos 1920 que sucedem à participação na Semana de Arte Moderna de São Paulo, em 1922, Monteiro esteve engajado na pesquisa da etnicidade brasileira, projeto comum aos demais modernistas brasileiros. Com as pinturas do periodo, garante presença no circuito artístico parisiense. Durante o entre-guerras, membro da "Escola de Paris", Monteiro inicia um período de escassa produção pictórica, o que é contrabalançado pela ampliação de suas relações de amizade. Quando se desfazem, paulatinamente, as bases para a assimilação do exotismo estrangeiro, no mercado de arte internacional, Monteiro se volta para o trabalho editorial, dirigindo revistas literárias na França e no Brasil. Com a sua La Presse à Bras, em 1946, finda a guerra, ele volta à capital francesa, manifestando de vez a personalidade cosmopolita até então refreada. Poeta de língua francesa e artista gráfico de renomada, Monteiro descarta a tarefa de realização de uma obra em estilo nativista, presente em suas pinturas até então praticadas. O expediente da flutuação de identidade que o fizera primitivista na Europa e monarquista no Brasil foi substituído pela figuração de si enquanto cidadão do mundo, homem urbano e cordial.

Sabendo da extrema importância que a sociabilidade de Monteiro contribuiu para a sua sobrevivência como artista estrangeiro na Paris dos anos 1920 e 1950, e de sua grande competência comunicativa, acreditamos que o jogo de cartas reencenaria as

8 Paul Ricoeur, em Soi-même comme un autre (1990), fundamenta uma nova ontologia segundo a distinção entre a identité-mêmeté, da consciência reflexiva, e identité-ipséité, da consciência projetiva, em uma dialética em que a alteridade não está colocada fora de si mas é constitutiva de sua ipséité mesma. 
estratégias do pintor-poeta, ao juntar imagem e texto no espírito da convivialidade linguageira, em que as regras vão sendo fixadas de acordo com as circunstâncias, característica maior do novo lirismo na modernidade, em que a identidade poética do autor é resultado de uma negociação deslocada da intimidade dos gabinetes para o espaço público dos cafés, dos ateliês, das redações de jornais, dos sindicatos e das corporações. Assim, agrupados em torno de uma mesa de jogo, os leitores de Cartomancie celebram a vitória da amizade.

Ao invés de partir de uma contradição, pensaríamos que a trajetória de Monteiro foi feita (com) tradição. Anamnese, nostalgia do que não foi, vestígio de dois tempos da história que escaparam a Monteiro e aos quais ele ficcionaliza: o da inspiração pré-colombiana com suas pinturas de inspiração marajoara e o da ética cavaleiresca com a metáfora naipesca. A tradição aparece como um texto ao qual o tempo todo ele contrapõe a temporalidade histórica e existencial do sujeito, agora desinvestido do privilégio do cogito triunfante.

Partindo de uma realidade brasileira em que o conceito de tradição é problemático, por ausência de um patrimônio escrito das suas populações autóctones, e pelas características eminentemente miscigenadas de sua cultura, muito mais voltada para a dissolução do que para a afirmação da identidade, Monteiro confere dimensão heróica à iconografia ameríndia, estilo reconhecidamente monumental de suas pinturas, ${ }^{9}$ o que acentua a estranheza dessa presença no contexto da arte européia. De um lado, por se tratar de uma combinação híbrida, no sentido de corpo feito com partes de outros corpos heterogêneos - o épico, de origem clássica, e o primitivo, anticlássco por definição --, de outro porque nessa "devoração" está implicado o seu próprio corpo, sem identidade definida, nascido de paternidade difícil de determinar no plano coletivo quando a

9 Pierre Rivas vê nas poesias de Monteiro "tentação épica", no contato com o conteúdo "agônico" da temática esportiva da qual Géo-Charles era o grande portador. Rivas sugere, a partir desta percepção, um "aspect singulier a téoriser: le rapport entre modernité et tradition, entre cosmopolitism parisien et enracinement brésilien", relação produtora de poemas que são "messages où apparaît la généreuse amitié de Monteiro entre deux mondes, l'ancien et le Nouveau" (RIVAS, Postface In: Emery. 1998, p. 173-177). Estas são algumas das pistas que procurei seguir. 
brasilidade foi resultado de um abastardamento dos padrões europeus de proveniência, levando adiante a metáfora antropófaga.

Seu medievalismo vai fazer avançar a ficcionalização, pois a intertextualidade se dá como aculturação do selvagem, adestramento do mestiço, aprendizado da civilização, com todos as implicações problemáticas do termo, em um movimento de trânsito do indivíduo, processo de despersonalização traumático mas necessário que o levara a afirmar cada vez mais a importância dos laços de amizade como saida para os ônus do exílio, horizonte de realização de um projeto ético gestado no entre-guerras.

O confronto e a assimilação das diferenças, implicados nesse processo, podemos observar desde as diversas experiências de paginação e tipografia no livro. Em Cartomancie, a utilização da metáfora naipesca e do formato baralho enfatiza a dualidade lírica por excelência: o amor e a morte, experiências limites, constroem uma projeção em abismo do sujeito fragmentado e disperso entre os participantes do jogo, enunciado como um enigma, possibilidade de leitura que o livro-baralho, desencadernado, oferece.

\section{Referências}

DUARTE, Claudia. Marcel Duchamp olhando o grande vidro como interface. Rio de Janeiro: Marca d'água. 2000.

BENJAMIN, Walter. A obra de arte na era de sua reprodutibilidade técnica. Rio de Janeiro: Paz e Terra, 1978.

BLANCHOT, Maurice. Le livre à venir, 1959

BRUSCKY, Paulo et al. Cartomancie (2. ed.). Recife: Bagaço, 1999.

CAMPOS, Haroldo de. A arte no horizonte do provável. São Paulo: Perspectiva, 1977.

ETIENVRE, Jean-Pierre. Márgenes literários de juelgo. Una poética del naipe. Siglos XVI-XVII. London: Tamesis, 1990.

CHARTIER, Roger. História da leitura no mundo ocidental. São Paulo: Ática: 1998

HAMON, Philippe. Imagéries, littérature et image au XIXème. siècle. Paris: José Corti, 2001.

HATHERLY, Ana. A casa das musas. Lisboa: Estampa, 1995. 
HEIDEGGER, Martin. A origem da obra de arte. Lisboa: Edições 70, 1990.

HORACIO, Arte poética. Lisboa, Clássica, s./d..

HUIZINGA, Johan. Homo ludens. Paris: Gallimard, 1951.

JOBIM, João Luis: A leitura e a produção textual: uma visão histórica. Revista TB. Rio de Janeiro, n²4, p. 127-141, 1996.

JOLLY; Martine. L'image et les signes. Paris: Nathan, 1994

LAPLANTINE, François. Le Brésil comme société hypercomplexe. Violences de rapports sociaux et cordialités de relations humaines. Textures, revista do CEMIA. Lyon: Université Lumière Lyon2, $\mathrm{n}^{\circ} 7$, p. 14-16, 2000.

LE MEN, Ségolène; SCOTT, David. La genèse du livre de peintre. Iconotextes. CRCD, Université Blaise Pascal. Clermont-Ferrand, p. 39-58, 1990.

MAULPOIX, Jean- Michel. La quatrième personne du singulier. Esquisse du portrait du sujet lyrique moderne. Figures du sujet lyrique, Paris: PUF, 1996.

MONTEIRO, Vincent. Cartomancie. Paris: La Presse à Bras, 1952.

PALASI, Philippe. Jeux de cartes et de l'oie héraldiques aux XVII et XVIII siècles. Cahiers: Picard, 2000.

PERRONE-MOYSES, Leyla. O poeta Vincent Monteiro. In: Catálogo da exposição retrospectiva de Vicente do Rego Monteiro, MACUSP, 1971

REE, Jonathan. Heidegger. São Paulo: Edunesp, 2000

RICOEUR, Paul. Soi-même comme un autre. Paris: Seuil, 1990.

RIVAS, Pierre. Postface. In: EMERY, Bernard. Brésil baroque, nouveau Brésil, la vision de Géo-Charles. Echirolles: CRELIT/ Musée Géo-Charles, 1998.

TODOROV, Tzevan. Mickail Bakhtine, le principe dialogique. Paris: Seuil, 1981

SILVEIRA, Paulo. A página violada. Porto Alegre: EdUFRS, 2001.

VILLAÇA, Alcides. Machado de Assis, tradutor de si mesmo. In: Novos Estudos CEBRAP. S. Paulo: julho de 1998. 